\title{
Fire Resistance Properties of Concrete upon using Bentonite
}

\author{
K. Anitha, T.P.Meikandaan, M.Hemapriya
}

\begin{abstract}
The experimental investigation on alternate concrete from aged volcanic ash or hydrated aluminium silicate was done by partially replacing bentonite with OPC. For industrial purpose bentonite is available in two forms sodium bentonite and calcium bentonite. The total resources of bentonite in the country as per UNFC system are about 531 million tonnes. The partial replacement of bentonite with cement leads to reduction of cement content in concrete mix. Concrete specimens were casted and examined for the 7th, 14th and 28th days respectively. A mix ratio of 1:2:4 was adopted for 0\%, 10\%, 20\%, $30 \%, 40 \%$ and $50 \%$ replacement of bentonite with cement. Test were conducted on fresh concrete and hardened concrete. Estimated results was computed for all concrete samples replaced with bentonite based on the test result done.
\end{abstract}

\section{Keywords - Experimental Investigation, Bentonite}

\section{INTRODUCTION}

Cement is a common bond in existence. The popularity as a construction material is due to its economy, durability, insulation property, thermal property, ability to be mould in to desired shapes and its beauty[1]-[7]. Concrete is defined as the combination of the coarse aggregate, fine aggregate and binding material such as cement or lime with convenient prescribed quantity of water. Here cement is the important component because, cement is binding material. Daily usage of cement generate large amount of carbon dioxide emissions which results in global warming and ozone layer depletion. The cost of naturally available material like Calcium Bentonite is very less compared to OPC. However the composition of Calcium Bentonite is similar to OPC. In many cases it has been proved that the naturally available material can solve the environmental damages for certain extend. Also in industries the waste products are tremendously increasing that may lead to ecological imbalance[8]. Thus by using the industrial wastes in concrete not only to solve the problem of waste disposal but also to effectively reduce the cost of concrete. The business significance of bentonite depends more on its physic-compound properties instead of its substance sythesis. Superb pliancy and lubricity, high dry-holding quality, high shear and compressive quality, low

Revised Manuscript Received on October 22, 2019.

K.Anitha, Department of Civil Engineering, Bharath Institute of Higher Education and Research, Chennai, India. Email: anithakrish26@yahoo.co.in T.P.Meikandaan, Department of Civil Engineering, Bharath Institute of Higher Education and Research, Chennai, India. Email: ganga_meik@yahoo.co.in

M.Hemapriya, Department of Civil Engineering, Bharath Institute of Higher Education and Research, Chennai, India. Email: meihemapriya@gmail.com porousness and low compressibility make bentonite significant.

A. Properties of Bentonite
Table 1 - Physical properties of bentonite
\begin{tabular}{|c|c|}
\hline Type & Non-Swelling Bentonite (Calcium) \\
\hline Specific gravity & 3.60 \\
\hline Bulk density $(\mathrm{g} / \mathrm{cc})$ & 0.60 \\
\hline
\end{tabular}

Table 2 - Chemical compositions of bentonite

\begin{tabular}{|l|l|l|}
\hline S.no & Chemical name & Values (\%) \\
\hline 1. & Manganese (Mn) & 0.022 \\
\hline 2. & Calcium (Ca) & 0.197 \\
\hline 3. & Potassium (k) & 0.486 \\
\hline 4. & Phosphorus (P) & 0.136 \\
\hline 5. & Titanium (Ti) & 1.803 \\
\hline 6. & Iron (Fe) & 4.759 \\
\hline 7. & Silica (Si) & 16.210 \\
\hline 8. & Aluminum (Al) & 5.752 \\
\hline
\end{tabular}

\section{EXPERIMENTAL PROGRAMME}

\section{A. Testing Of Specimens}

The following tests procedures are illustrated below as per IS456:2000

1 )18 No's of cube size $150 \mathrm{~mm} \times 150 \mathrm{~mm} \times 150 \mathrm{~mm}$ were casted using M20 grade concrete. Specimens with Ordinary Portland Cement (OPC) were used [9]-[12].

2) 6 Nos. of cylinders of size $150 \mathrm{~mm}$ diameter and $300 \mathrm{~mm}$ height were casted for the split tensile strength test

3) OPC was replaced with bentonite powder at $10 \%, 20 \%$, $30 \%, 40 \%$ and $50 \%$.

\section{RESULTS AND DISCUSSIONS}

Various properties of concrete incorporating bentonite at various replacement levels with fine aggregate levels were studied; results were compared and checked for compressive strength, of bentonite mix with ordinary mix. Test results were compared and shown in below table $1[13]$ 
Table - 3 Comparison of compression strength for M20 Concrete

\begin{tabular}{|c|c|c|c|c|c|c|c|c|c|c|c|c|c|c|}
\hline \multicolumn{3}{|c|}{$\begin{array}{l}\text { Nominal concete } \\
\text { M20 }\end{array}$} & \multicolumn{3}{|c|}{$\begin{array}{l}\text { With Bentonite } \\
\text { (30\% added) }\end{array}$} & \multicolumn{3}{|c|}{$\begin{array}{c}\text { With Bentonite } \\
(30 \% \text { added }) 7 \text { days }\end{array}$} & \multicolumn{3}{|c|}{\begin{tabular}{|c|} 
With Bentonite \\
$(30 \%$ added) 14 days
\end{tabular}} & \multicolumn{3}{|c|}{$\begin{array}{c}\text { With Bentonite } \\
(30 \% \text { added) } 28 \text { days }\end{array}$} \\
\hline $\begin{array}{l}7 \\
\text { days }\end{array}$ & \begin{tabular}{|l|}
14 \\
days
\end{tabular} & $\begin{array}{l}28 \\
\text { days }\end{array}$ & $\begin{array}{l}7 \\
\text { days }\end{array}$ & $\begin{array}{l}14 \\
\text { days }\end{array}$ & \begin{tabular}{|l|}
28 \\
days
\end{tabular} & $50^{\circ} \mathrm{c}$ & $75^{\circ} \mathrm{C}$ & $100^{\circ} \mathrm{c}$ & $50^{\circ} \mathrm{C}$ & $75^{\circ} \mathrm{C}$ & $\begin{array}{l}100^{\circ} \\
c\end{array}$ & $50^{\circ} \mathrm{C}$ & $75^{\circ} \mathrm{C}$ & $100^{\circ} \mathrm{c}$ \\
\hline 4.38 & 17.19 & 21.94 & 13.91 & 17.12 & 22.87 & 14.42 & 14.12 & 13.97 & 16.75 & 16.42 & 16.05 & 14.38 & 17.19 & 21.94 \\
\hline
\end{tabular}

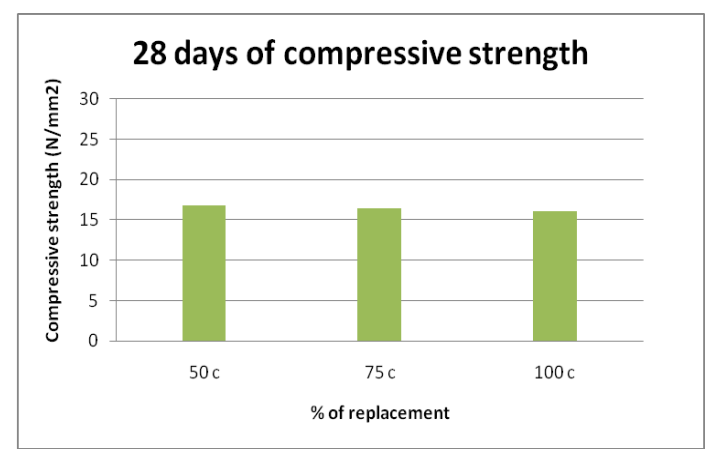

Figure $-128^{\text {th }}$ day Compressive Strength Test

\section{CONCLUSION}

From the Experimental Investigation, replacement of cement with bentonite powder at $30 \%$ gives maximum strength and it is most economical one compared to normal concrete. Utilization of cement is reduced while using bentonite powder. Environmental effects due to the cement manufacturing are reduced through this project. The compression strength increases for added $30 \%$ bentonite, compare to nominal concrete $7,14, \& 28$ days. The compression strength decreases for added $30 \%$ bentonite concrete cube at $500 \mathrm{C}, 750 \mathrm{C}, \& 1000 \mathrm{C}$.

\section{REFERENCES}

1. Sathish Kumar, K., Vinothkumar, S., Venkatakrishnaiah, R. \& Mohan, S.J. 2019, "Experimental investigation on rehabilitation of corroded concrete beam specimens", International Journal of Civil Engineering and Technology, vol. 10, no. 1, pp. 2949-2955.

2. Kanchanabhan, T.E., Krishnaiah, R.V., Dayakar, P. and Mani, A., 2019. A detailed study on green building concept in construction industry. International Journal of Civil Engineering and Technology, 10(1), pp. 2944-2948.

3. Mugilvani, P., Murugan, S.T., Kaviya, B. and Sathishkumar, K., 2019. Experimental investigation on nano concrete. International Journal of Civil Engineering and Technology, 10(1), pp. 907-912.

4. Vinothkumar, S., Sathishkumar, K., Anish, C. and Rajesh, S., 2019. Characteristic strength of concrete by partial replacement with sawdust and waste ceramic tiles. International Journal of Civil Engineering and Technology, 10(1), pp. 2821-2829.

5. Chitra, R., Thendral, S., Arunya, A. and Mohan, S.J., 2019. Experimental study on strength of concrete by partial replacement of fine aggregate with saw dust. International Journal of Civil Engineering and Technology, 10(1), pp. 2766-2769.

6. Mani, A., Meikandaan, T.P., Gowrishankar, P.G. and Kanchanabhan, T.E., 2019. A study on treatment of industrial effluent (dyeing) using moringa oleifera, tamarina indica as coagulants. International Journal of Civil Engineering and Technology, 10(1), pp. 2796-2811.

7. Frank Stephen, S., Chockalingam, M.P., Nalanth, N. and Lekshmy Raghavan, P., 2019. Study on the fresh state properties of self compacting concrete modified with recycled concrete aggregate.
International Journal of Civil Engineering and Technology, 10(1), pp. $1205-1212$

8. Dayakar, P., Raman, K.V., Arunya, A. and Venkatakrishnaiah, R., 2019. Study on strength properties of sand by biocementation with eggshell. International Journal of Civil Engineering and Technology, 10(1), pp. 2770-2785.

9. Shendge, R.B., Chockalingam, M.P., Saritha, B. and Ambica, A., 2018. Swat modelling for sediment yield: A case study of Ujjani reservoir in Maharashtra, India. International Journal of Civil Engineering and Technology, 9(1), pp. 245-252.

10. Meikandaan, T.P. and Hemapriya, M., 2017. Use of glass FRP sheets as external flexural reinforcement in RCC Beam International Journal of Civil Engineering and Technology, 8(8), pp. $1485-1501$

11. Harini, A.T., 2017. Experimental study on utilisation of ceramic wastes in concrete. International Journal of Civil Engineering and Technology, 8(8), pp. 1346-1352.

12. Ambica, A., Sartiha, B. and Anbarasan, R., 2017. Groundwater quality assessment using water quality index and GIS, Maduravoyal, Chennai, India. International Journal of Civil Engineering and Technology, 8(8), pp. 1375-1381.

13. Aswathy, M., Saritha, B. and Chockalingam, M.P., 2019. Degradation of anionic dye using Fe/Tio2 composite by photocatalysis. International Journal of Innovative Technology and Exploring Engineering, 8(9 Special Issue 3), pp. 788-791

\section{AUTHORS PROFILE}

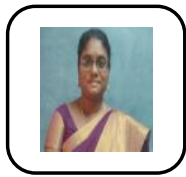

K.Anitha Assistant Professor, Department of Civil Engineering, Bharath Institute of Higher Education and Research, Chennai , India.

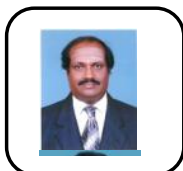

T.P.Meikandaan Associate Professor, Department of Civil Engineering, Bharath Institute of Higher Education and Research, Chennai, India.

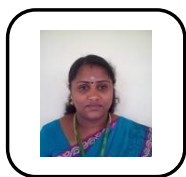

M.Hemapriya Assistant Professor, Department of Civil Engineering, Bharath Institute of Higher Education and Research, Chennai , India. 